\title{
Nasogastric Tube
}

National Cancer Institute

\section{Source}

National Cancer Institute. Nasogastric Tube. NCI Thesaurus. Code C93310.

A hollow tube that is directed into the stomach from the nose. 